\title{
A resistant pepper used as a trap cover crop in vegetable production strongly decreases root-knot nematode infestation in soil
}

\author{
Mireille Navarrete $^{1}$ (1) $\cdot$ Caroline Djian-Caporalino ${ }^{2} \cdot$ Thierrry Mateille $^{3}$. \\ Alain Palloix ${ }^{4}$ - Anne-Marie Sage-Palloix ${ }^{4}$ - Amélie Lefèvre ${ }^{5}$ - Ariane Fazari ${ }^{2}$. \\ Nathalie Marteu $^{2}$ - Johannes Tavoillot ${ }^{3}$ - Arnaud Dufils ${ }^{1} \cdot$ Claudine Furnion $^{1}$. \\ Laure Pares $^{5}$ - Isabelle Forest ${ }^{6}$
}

\begin{abstract}
Root-knot nematodes are causing serious economic losses of vegetable production. Actual agroecological control solutions are not effective enough to control this pest or are difficult to implement in farms. There is little knowledge on the use of crops to trap nematodes in protected cultivation systems. Therefore, we tested a resistant pepper as a trap crop for root-knot nematodes over 4 years in a commercial farm and an experimental station in Southern France. The effects of pepper trap crop on plant damages and soil infestation were compared with a sorghum cover crop. We also surveyed 28 local vegetable farmers for their interest concerning the possible use of the pepper trap crop. Our results show that nematode infestation of the soil decreased by 99 and $80 \%$ after the first and second implementation of the trap crop. The gall index measured on Swiss chard decreased from 2.5 to less
\end{abstract}

Alain Palloix has passed away prior to the publication of this article.

Mireille Navarrete

mireille.navarrete@inra.fr

INRA UR767, Ecodéveloppement, 228 route de l'aérodrome, 84914 Avignon cedex 09, France

2 INRA UMR 1355, Institut Sophia Agrobiotech, 400 route des Chappes, 06903 Sophia, France

3 IRD UMR CBGP, 755 Avenue du Campus de Baillarguet Agropolis, 34988 Montferrier Sur Lez, France

4 INRA UR1052, Génétique et Amélioration des Fruits et Légumes, 84143 Montfavet Cedex 09, France

5 INRA UE0411, Domaine Expérimental d'Alénya Roussillon, 66200 Alénya, France

6 Chambre d'Agriculture du Var, 727 avenue Alfred Décugis, 83400 Hyères, France than 1 after 4 years. Respectively, 21 and $36 \%$ of farmers found the cropping system completely and partially acceptable. The most interested farmers were those having sufficient labor and available land in summer. Farmer criticisms were higher nursery costs and planting duration, versus sorghum. Overall, this is the first design of a cropping system using a resistant cultivar as a dead-end trap crop for root-knot nematodes. The process used, moving from a genetic construct to agronomic innovation through an interdisciplinary and participatory approach, holds promise for scientists seeking new integrated pest management approaches to increase the sustainability of agriculture.

Keywords IPM · Vegetable $\cdot$ Cropping system · Design · Experiment · Protected cultivation · Trap crop · Genetic resistance $\cdot$ Agroecology $\cdot$ Innovation $\cdot$ Acceptability to farmers $\cdot$ Meloidogyne

\section{Introduction}

Root-knot nematodes (Meloidogyne spp., RKNs) are causing increasing economic losses worldwide, particularly in vegetable crops. Average yield losses of $10 \%$ have frequently been reported, but much higher percentages have been reported in local conditions. For example, Sikora and Fernandez (2005) reported up to $30 \%$ crop losses on highly susceptible plants, such as tomato, melon, and eggplant. In South of France, RKN symptoms have been recorded on more than $40 \%$ of vegetable farms (Djian-Caporalino 2012). These figures call into question the future of vegetable crops, because such high levels of infestation jeopardize profitability. 
There are several reasons for these high levels of infestation in protected cultivation. First, the predominant RKN species in Mediterranean areas ( $M$. arenaria and $M$. incognita) are extremely polyphagous (Djian-Caporalino 2012). They are host of numerous commercial species, including plants from three families overrepresented among crops grown under glass or plastic: Solanaceae, Cucurbitaceae, and Asteraceae (Sikora and Fernandez 2005). Second, climate change is leading to higher RKN survival rates, particularly as soils under shelters are warmer than are those in open fields. Finally, the use of chemical nematicides has gradually been restricted for environmental reasons and due to undesirable effects on health (Zasada et al. 2010). Several agroecological techniques are known to affect RKNs (Zasada et al. 2010; Collange et al. 2011): sanitation, soil tillage, organic amendment, nematicidal green manure, biological control, heat-based methods, and plant resistance etc. Each of these techniques is only partly effective, necessitating their combination, which further complicates their adoption on farms where space available under shelters for non-commercial practices is very limited (Collange et al. 2014). Breeders are mostly focusing on the introgression of resistance genes (R-genes) into commercial cultivars or rootstocks, a strategy with several limitations. First, few R-genes have been identified and used in vegetable crops so far: the Mi-1 gene in tomato (Milligan et al. 1998) and the N, Mel and Me3 genes in sweet pepper (Hare 1957; Hendy et al. 1985). Second, the $M i-1$ gene is inactive at soil temperatures above $28{ }^{\circ} \mathrm{C}$, which are frequently encountered under shelters in summer in Mediterranean areas, whereas the efficacy of $M e$ genes is not temperature-dependent (DjianCaporalino et al. 1999). Finally, the use of R-genes makes it possible to grow vegetables in infested soils but decreases soil contamination only slightly because of the low planting density. In the long term, R-genes tend to be overcome by the pest, as shown recently for $N$ and $M e 3$ in pepper (Thies 2011; Djian-Caporalino et al. 2011). By contrast, the pepper $\mathrm{Mel}$ gene has never yet been overcome in laboratory or field conditions (Djian-Caporalino et al. 2011, 2014). The use of a hybrid pepper in which the $\mathrm{Mel}$ and $\mathrm{Me} 3$ genes are pyramided has proved highly effective for the protection of subsequent crops, as it strongly decreases the soil infection potential in the long term (Djian-Caporalino et al. 2014). Could such a MelMe3 hybrid pepper be used to trap RKNs in infested soils?

Trapping is mostly used for managing aerial pests. Some studies have been realized on soil-borne pests, but very few are available on vegetable production. Nematode trap plants have been tested periodically since the late 1900s. For example Solanum sisymbriifolium (Dandurand et al. 2013) against potato cyst nematodes Globodera, aragula (Eruca sativa), marigold (Tagetes patula), and cowpea (Vigna unguiculata) against Meloidogyne spp. (McSorley et al., 1999, Wang et al. 2003, Roberts et al. 2005, Hooks et al. 2010, Melakeberhan et al. 2010). In these studies, nematologists focused on the trapping mechanisms and tried to disentangle the respective roles of trapping and toxic compound release (a question remaining open for marigold as reviewed by Hooks et al. 2010). After inoculating nematodes in pots of soil, they compared the population density before and after the trap crop in very controlled conditions and most often concluded to a significant decrease in population density in the soil thanks to the trap crop.

Although the interest in using such basic knowledge to control nematodes in field conditions is mentioned in the literature, it is hardly ever studied. In particular, very few studies measure the efficacy on the following crop. Two cases must be distinguished depending if the trapping is permanent or not. When host plants as lettuce and radish are cropped, the trapping process is not permanent: host plants attract juveniles, but plant root systems must be completely removed from the soil before the end of the RKN life cycle to prevent nematode reproduction in those roots and consequent nematode increase in soil (Cuadra et al. 2000). This is therefore difficult to implement in commercial farms and very risky when growers are overloaded. Using dead-end trap crops is more promising. The potential of cowpea, a legume frequent in tropical Asia and West Africa, received much attention. Roberts et al. (2005) analyzed the effect of a resistant cowpea cover crop for protecting the following susceptible tomato crop from $M$. incognita. Both the cover crop and the following tomato crop were protected from RKN infestation, but the resistant genes $\mathrm{Rk}$ and $\mathrm{Rk} 2$ did not provide a full protection when soils were highly infested. The long-term effects beyond the first crop were not analyzed in depth, but Wang et al. (2003) consider that RKN suppression is rather short-lived. Finally, most of the species liable to be used as trap crop are difficult to introduce into vegetable crop rotations (Djian-Caporalino et al. 2005), or the technique is not operational yet.

Therefore, we searched for developing an innovative cropping strategy in which the hybrid-resistant pepper was used as a dead-end trap crop, attracting RKN juveniles in the soil, and preventing their progeny from developing. This strategy has several advantages. The two genes are complementary and efficiently trap RKNs; their activity is stable at high temperature; and there is a low risk of overcoming their combined resistance (Djian-Caporalino et al. 2014). They definitively trap nematodes within the roots. Finally, the use of this pepper as a cover crop between two cash crops should facilitate its introduction into highly constrained cropping systems. Our research project brought together scientists (agronomists, agricultural scientists, geneticists, and nematologists), technical advisers, and farmers to design an efficient cropping system and suitable for use on commercial farms (Navarrete et al. 2010). We present results on its multidimensional assessment and on its acceptability to farmers, from two complementary approaches: experimentation and a farmers' survey. 


\section{Materials and methods}

As pointed out previously, RKN trapping has been largely studied by nematologists. Nevertheless, which crop management plan is able to optimize the trapping process has never been explored, neither is its long-term efficacy. We therefore describe first how the crop management plan was chosen, based on the available basic knowledge of the RKN life cycle and trapping mechanisms and of the operational knowledge of farmers' constraints to implement new practices (2.1). Then, the methods used for the multidimensional assessment are described: the experimental device to assess the pepper efficacy as a trap crop and as a cover crop (2.2) and the farm survey to estimate the acceptability of this system to farmers.

\subsection{Design of an innovative crop management plan for the pepper trap crop}

\subsubsection{Potential for RKN trapping with resistance genes}

RKNs are obligate plant endoparasites that can complete several generations per year under shelters (Sikora and Fernandez 2005). Mature females lay eggs on the root surface or embedded in galls. Following embryogenesis, the first-stage juvenile (J1) molts within the egg to generate the infective second-stage juvenile (J2), which hatches from the egg. J2s are the only stage mobile in the soil, but their active dispersal is restricted to a range of 10-20 cm (Prot and Van Gundy 1981). In susceptible plants, the J2s initiate the formation of giant cells for feeding; they then molt three times to generate reproductive adults. The lifecycle is shorter in warm conditions: 63 days at $16{ }^{\circ} \mathrm{C}$ and 20 days at $30{ }^{\circ} \mathrm{C}$ (Ploeg and Maris 1999).

Previous experimental studies have shown that $\mathrm{Mel}$ and $M e 3$ have different modes of action (Djian-Caporalino et al. 2011). Me3 induces early cellular necrosis in the root epidermis adjacent to juveniles, whereas $\mathrm{Mel}$ induces a late hypersensitive reaction in the vascular cylinder of infected roots, preventing the development of egg-laying females (Hendy et al. 1985; Bleve-Zacheo et al. 1998). In both cases, the nematodes die in the roots without reproducing. Growth of the $\mathrm{Me} 1-\mathrm{Me} 3$ hybrid on microplots for 5 months strongly decreased soil infection potential, by up to $97 \%$ during 3 years after the trap crop. This decrease was almost complete on some microplots, on which organic amendment and fertiirrigation favored the development of hairy rooting systems (Djian-Caporalino et al. 2014). As nematodes are killed in the roots, it overcomes the need to destroy the plants before the end of the nematode life cycle. This aspect led us to consider the hybrid as a good potential new trap crop, provided that the rooting density is high.
2.1.2 Farmers' constraints limiting the widespread adoption of the trap crop

The main farmers' constraints in using an R-pepper trap crop result from the highly intensive nature of vegetable cropping under plastic shelters to obtain the best returns on investment. Crop rotations and planting schemes greatly influence the capacity of farmers to adopt new practices, such as soil solarization to replace chemical disinfestation (Navarrete et al. 2006). Indeed, the number of vegetable species cropped and their temporal and spatial arrangement depend principally on the farmers' marketing strategy and the characteristics of the farm, rather than crop health considerations. For instance, farmers using short marketing channels, who crop a wider range of vegetable species all year long, have very little available space and time for the introduction of a cover crop (Navarrete et al. 2015). By contrast, farmers using long marketing channels specialize in the cultivation of only a few species, potentially leading to soil health problems. But, they have room available for green manure crops during certain periods of the year to maintain soil fertility and health. We therefore assumed that the capacity to adopt the new cropping system would depend on such farm characteristics.

Under shelter, cover cropping is possible during two periods of the year. For plots free in the summer (e.g., after melon or zucchini crops), the most frequent species used are Sorghum Sudangrass (Sorghum sudanense) and Sudangrass hybrids (S. bicolor $x$ S. sudanense), grown from July to August. They improve soil structure through their deep rooting and enrich the soil with large amounts of fresh organic matter, thereby improving soil health (Abawi and Widmer 2000; Collange et al. 2011). If the cash crop is still present in the summer (e.g., tomato, sweet pepper), cover cropping can be carried out in the fall, with Brassicaceae such as forage radish or mustard, which produce biocidal chemicals for biofumigation (Collange et al. 2011). Cost is another key issue, limiting cover crop practices to a minimum. The only cropping practice required after soil tillage and sowing is sprinkler irrigation. After the cover crop has been growing for 1.5 to 2 months, the leaves and shoots are chopped into small pieces and incorporated into the soil. The direct cost of this system has been estimated at about 250-300 €/ha for sorghum (Crestin and Vannier 2007).

\subsubsection{A crop management plan for controlling RKNs compatible with farmers' constraints}

Based on information from Sects. 2.1.1 and 2.1.2, the scientists and advisors involved in the participatory project suggested growing the hybrid pepper in the summer. The crop management plan was largely based on the cropping techniques used for sorghum but with the key difference that the pepper plants had to be sown in peat plugs in a nursery before 
transplantation in the field, because pepper seeds require warm temperatures (above $23{ }^{\circ} \mathrm{C}$ ) and a favorable substrate for normal germination and growth. This additional step increased costs but was necessary to ensure that well-developed seedlings were planted. The seedlings were initially transplanted directly into tilled soil, but this necessitated manual weeding, because the weeds grew faster than did the peppers. We therefore decided to plant the seedlings on a biodegradable mulching film that could be incorporated into the soil at the end of cropping. J2 juveniles are not very mobile and are unlikely to reach the roots through their own displacement alone, so the roots needed to grow toward them. A planting density of 12 plants $/ \mathrm{m}^{2}$ was assumed to be sufficient for full exploration of the soil by the roots. Summer is the most favorable season for trapping RKNs because the life cycle is shortened by warm temperatures. According to Pegard et al. (2005), the J2 juveniles are rapidly trapped after they enter the roots. We therefore considered a 6-week period to be sufficient to allow all the eggs to develop into $\mathrm{J} 2$ juveniles and for these juveniles to be trapped. Moreover, the growing period was assumed to be long enough to produce sufficient organic matter to fulfill the role classically played by sorghum. At the end of the pepper crop, as RKNs are unable to leave the roots, the rooting system was left in place, and the shoots and leaves were incorporated into the soil (Fig. 1).

\subsection{Assessment of the agronomic impact of the pepper crop}

\subsubsection{Experimental device and growing conditions}

Two 4-year trials were performed, one on a commercial farm and the other at an experimental station under high plastic tunnels (about $8 \mathrm{~m}$ wide and $3.5 \mathrm{~m}$ high) (Table 1a). Each trial consisted of two periods of 2 years, each with the same sequence of crops, to assess the likely long-term and cumulative effects of the alternative cropping system. The pepper cover crop was cropped every other year (in the first and third years): it was assumed that this frequency was sufficient to control RKNs in the long term. After the trap crop, susceptible species were grown to determine the extent to which the soil had been disinfected. Two types were used: partially susceptible crops, such as lettuce and $M i$ tomato (the resistance of which is overcome at high temperature), and very susceptible crops, such as melon. The crop rotation in the farm trial was Swiss chard - pepper or sorghum cover crop (year 1), lettuce-Mil tomato (year 2), lettuce - melon - pepper or sorghum cover crop (year 3), lettuce-Mil tomato-Swiss chard (year 4). At experimental station, the first and last Swiss chard crops were replaced with lettuce crops. In each trial, the plot was divided into two subplots; the cropping system with a pepper trap crop was compared with a control cropping system including a sorghum cover crop. The first trial was carried on a farm located in Six-Fours (43.1 N, 5.85 E, Var). The $125-\mathrm{m}^{2}$ plot had a sandy-clay soil, with $1.8 \%$ organic matter, and had been heavily infested with $M$. arenaria since the 1980s. The second trial was conducted on a $320-\mathrm{m}^{2}$ plot at the INRA experimental station at Alénya (42.6 N, 2.98 E, Pyrénées-Orientales), on a loamy-sand soil containing $1.8 \%$ organic matter. We aimed (i) to measure additional variables that could not be measured on a commercial farm, such as the dynamics of soil colonization by the roots over the cropping cycle and (ii) to refine the pepper crop management plan. In 2013, the same planting density ( 12 plants $/ \mathrm{m}^{2}$ ) was used. In 2015 , two planting densities were compared ( 9 and 12 plants $/ \mathrm{m}^{2}$ ), to assess the feasibility of reducing costs by using a lower density. These data could not be acquired a farm, and this made it necessary to carry out the trial in a soil without RKNs.

For the on-farm trial, the pepper seeds (Me1-Me3) were sown in a nursery on $4 \times 4$-cm plug trays on April 27, 2012 and June 24, 2014 and were maintained at $25^{\circ} \mathrm{C}$. One month later, the seedlings were transplanted to the experimental plot, at a density of 12 plants $/ \mathrm{m}^{2}$, to bare soil in 2012 and to soil covered with a biodegradable film in 2014 (see Sect. 2.1.3). The soil was rototilled and refined before planting. In 2012 only, $10 / 40 / 10$ mineral fertilizer $\left(20 \mathrm{~kg} / \mathrm{m}^{2}\right)$ was incorporated into the soil, which was considered to contain too few nutrients for satisfactory growth. After planting, the crop was irrigated three times per week. At the end of the trial, the plants, which were $1.20 \mathrm{~m}$ high, were incorporated into the soil with a rotavator, together with the biodegradable film. The cropping schedule for Alénya trial is indicated on Table 1. On Sorghum subplots, Sorghum was grown in accordance with local technical recommendations (Crestin and Vannier 2007), as
Fig. 1 The pepper cover crop under shelter in Alénya station (2013). The pepper was planted on a biodegradable film (a). At the end of the trial (b), the crop was chopped as well as the biodegradable film and incorporated into the soil (left part of the picture)

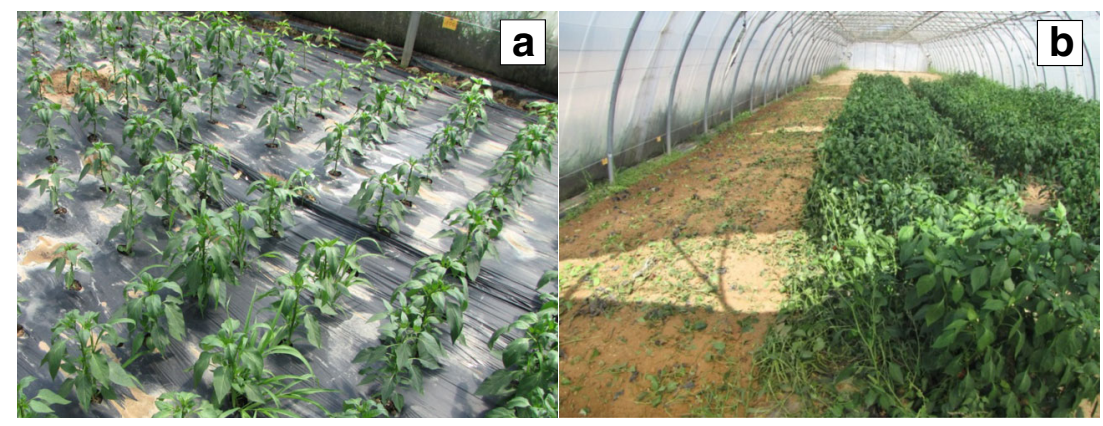


Table 1 Experimental device

$\begin{array}{llll}\text { Commercial farm, Six-Fours } & & & \text { Experimental station, Alénya } \\ 2012 & 2014 & 2013\end{array}$

\begin{tabular}{|c|c|c|c|c|}
\hline \multicolumn{5}{|l|}{ a. Cropping schedule } \\
\hline \multicolumn{5}{|l|}{ Pepper crop } \\
\hline Planting density $\left(\mathrm{pl} / \mathrm{m}^{2}\right)$ & 12 & 12 & 12 & 9 and 12 \\
\hline Sowing date & $27 / 04$ & $24 / 06$ & $04 / 04(0)$ & 04/06 (0) \\
\hline Planting date & $29 / 05$ & $27 / 08$ & $14 / 05(237)$ & 07/07 (426) \\
\hline End of the crop & $29 / 08$ & $14 / 11$ & $24 / 07(621)$ & 25/08 (917) \\
\hline \multicolumn{5}{|l|}{ Control: sorghum crop } \\
\hline Sowing date & $29 / 05$ & $11 / 09$ & $14 / 05(237)$ & 07/07 (426) \\
\hline End of the crop & $28 / 07$ & $09 / 10$ & 05/07 (444) & $20 / 08(857)$ \\
\hline \multicolumn{5}{|l|}{ b. Variables measured } \\
\hline Root-gall index (0-10) & \multicolumn{2}{|c|}{$\begin{array}{l}\text { 25-30 plants per treatment, on } \\
\text { each susceptible crop of the } \\
\text { rotation, } 10 \text { dates over } 4 \text { years }\end{array}$} & - & - \\
\hline $\begin{array}{l}\text { Soil infestation with RKN } \\
\quad \text { (number per } \mathrm{dm}^{3} \text { of fresh soil) }\end{array}$ & \multicolumn{2}{|c|}{$\begin{array}{l}7 \text { samples per treatment, } 9 \text { dates } \\
\text { over } 4 \text { years }\end{array}$} & - & - \\
\hline Pepper rooting system observation & \multicolumn{2}{|l|}{-} & $\begin{array}{l}06 / 06,18 / 06,02 / 07 \text { and } 24 / 07,6 \text { plants } \\
\text { per date }\end{array}$ & $\begin{array}{l}30 / 07 \text { and } 18 / 08,6 \text { plants per } \\
\text { date and per planting density }\end{array}$ \\
\hline $\begin{array}{l}\text { Pepper aboveground fresh and } \\
\text { dry weight }\left(\mathrm{g} / \mathrm{m}^{2}\right)\end{array}$ & \multicolumn{2}{|l|}{-} & $1 \mathrm{~m}^{2}$ microplot, 4 replicates on $24 / 07$ & $1 \mathrm{~m}^{2}$ microplot, 4 replicates on $25 / 08$ \\
\hline $\begin{array}{l}\mathrm{C} / \mathrm{N} \text { ratio of the aboveground } \\
\text { part on pepper and sorghum }\end{array}$ & \multicolumn{2}{|l|}{-} & - & $1 \mathrm{~m}^{2}$ microplot, 4 replicates, on $25 / 08$ \\
\hline
\end{tabular}

The numbers in brackets indicate the cumulative number of degree-days from sowing with a base value of $15^{\circ} \mathrm{C}$, the minimum temperature compatible with pepper growth

indicated in Sect. 2.1.2. The seeds (cv. Lussi in 2012 and cv. Piper in 2014 in Six-Fours, cv. Piper in 2013 and 2015 in Alénya) were sown at a density of $50 \mathrm{~kg} / \mathrm{ha}$. The other crops and their management were strictly identical between the treatment and control systems.

\subsubsection{Variables measured and data analysis (Table 1b)}

To estimate RKN damages on plants, the gall index was determined on the rooting system of a representative sample ( 25 to 30 plants per subplot) of each susceptible crop (e.g., lettuce, melon) on a scale of 0 to 10 (Zeck 1971). The infestation of the soil with RKN was determined on 250-ml samples of rhizosphere soil, at a depth of $15 \mathrm{~cm}$, before the experiment and after each trap and susceptible crops. Over the 4-year period, samples were always taken from the same site, to within $10 \mathrm{~cm}$, for each replicate, to take possible heterogeneity in the distribution of RKNs over the plot into account. RKNs were extracted by the Seinhorst (1962) elutriation procedure. They were counted in $5-\mathrm{cm}^{3}$ counting chambers, under a stereomicroscope ( $\times 40$ magnification).

For rooting observations at the experimental station, four pits were dug in 2013 and two in 2015, alongside six pepper plants in the same row ( $1.5 \mathrm{~m}$ long, $0.7 \mathrm{~m}$ deep). A grid of $2 \times 2$-cm cells was applied vertically to the soil profile to count the number of roots per cell. We determined the number of cells occupied by at least one root, to estimate the proportion of soil potentially disinfected by the trap crop. As nematodes can cover distances of about $10 \mathrm{~cm}$, we assumed that only those located in cells containing one or more roots could be trapped.

For evaluation of pepper growth on the experimental station, at the end of the crop, the fresh and dry weights of the aboveground parts of the plants were determined for four replicates per treatment: the plants from a $1-\mathrm{m}^{2}$ microplot were weighed before and after drying in an oven at $50{ }^{\circ} \mathrm{C}$ for $48 \mathrm{~h}$. A subsample of each replicate was used to measure total $\mathrm{N}$ and total $\mathrm{C}$ concentrations by elemental analyses based on the Dumas method (Elementar VarioMacroCube CHN, Germany).

Mean values and standard deviations were used to compare the alternative cropping system to the control for each date. The dynamics of gall index and soil infestation with RKN over the 4 years were studied to detect possible longterm effects of the pepper trap crop. The dynamics of rooting was studied to determine the optimal length of the trap crop. 
2.3 A survey to estimate the acceptability of the trap crop innovation to farmers

A farm survey was carried out in 2014 in Provence $(30 \mathrm{~km}$ around Avignon), in an area widely contaminated with RKNs. We selected 28 vegetable farmers reporting RKN damage, on the basis of farm size, crop diversity, and marketing channels (Furnion 2014). The cropping practices ranged from conventional to more environment-friendly or organic systems. Farmers were first asked to describe the functioning of their farm: cropping systems (rotations, crop management plans, and cropping schedules), available resources (open field and sheltered areas, labor force, tillage machinery, etc.), and their marketing strategy. Then, they were asked about the feasibility of using the pepper trap crop on their own farm. Based on a graphic support mapping out, on a timeline, the farmers' cropping systems and the innovative one, the farmers identified the main changes they would have to make, and the difficulties they would face if they adopted the innovative system. The interviews, based on a semistructured questionnaire, lasted about 1.5 to $2 \mathrm{~h}$ and were recorded.

The 28 interviews were analyzed by coding the farm characteristics (area, number of species cropped, degree of ecologization, RKN pressure, marketing channels), the farming style (motivation for agroecology and for technical innovation, perception on RKN management), and the acceptability of the innovative cropping system. The acceptability was decomposed into three components: compatibility of cropping calendars between the innovative and current cropping systems ("Cal"), work issues ("Work"), and marketing issues ("Mkt"). Two typologies were built by multiple correspondence analyses (MCAs) and hierarchical clustering on principal components ( $\mathrm{R}$ software): one of farms and one of farmers' farming styles. The acceptability components were compared with these two typologies.

\section{Results and discussion}

\subsection{Impact of the innovative cropping system on RKN control}

\subsubsection{RKN dynamics in soil}

In the on-farm trial, RKN abundance in the soil decreased sharply after each pepper crop (Fig. 2a), by up to $99 \%$ in 2012 and $80 \%$ in 2014. However, this decrease was similar to that after the sorghum crop, which was supposed to have limited effects on RKNs. In controlled conditions, we showed that the sorghum cultivars used (Piper and Lussi) allowed RKNs to multiply over 2-month periods of cultivation in warm conditions (data not shown), which is the common practice in the area studied. This may account for their usually limited control effect on RKNs. In this experiment, sorghum was incorporated into the soil before the completion of the RKN life cycle (because of a short period in 2015 and cooler conditions in 2013). It may, therefore, have acted as a temporary trap crop, reducing $\mathrm{RKN}$ infestation to levels similar to those achieved with the pepper crops. But, this unintentional effect conceals the high risk of RKN multiplication if the sorghum crop is destroyed too late, as indicated by Cuadra et al. (2000) for other trap species. After the pepper and sorghum crops, the RKN population in the soil remained small, even after the susceptible lettuce and partially resistant tomato crops. However, it increased again during the second year after the melon crop, probably not only because melon is highly susceptible but also because of the long period from the last trap crop. It confirms our hypothesis that a trap crop frequency of one every 2 years is mandatory to maintain RKN populations below an alarming level. The results are very interesting because previous studies indicated that the efficacy of the other trap crop studied (especially cowpea) was rather short lived (Wang et al. 2003).

The results for RKN dynamics in soil were confirmed by the gall index recorded for the roots of RKN-susceptible plants. After the pepper trap crop, the gall index was very low on lettuce (less than 1 on a $0-10$ scale at times 5 and 33) (Fig. 2b). When lettuce is cropped in the fall when RKNs are still very active, the gall index for these plants can reach the maximum level of 10 (Djian-Caporalino et al. 2014). The two cover crops were, therefore, effective for RKN control. The highest gall index, about 6 , was found on the melon (time 26), which is highly susceptible: nematodes multiplied substantially on this crop, resulting in a high abundance of nematodes in the soil at the end of the crop. On Swiss chard, gall index decreased from 2.5 to 3 before the trial (time 0 ) to 1 at the end of the trial (time 48), confirming the efficacy of both trap crops for decreasing soil infection potential. These results are consistent with and extend those previously obtained on microplots (Djian-Caporalino et al. 2014). But, they were obtained after a much shorter period (2 months instead of 6), which confirms that the Mel-Me3 pepper can be cropped as a short cover crop.

\subsubsection{Potential of pepper roots to colonize the soil and trap RKNS}

Cover crops are usually intended to enrich the soil with organic matter and improve soil fertility; what is the potential of the pepper crop as a green manure? During the pepper crop cycle in 2013 at Alénya station, the roots gradually spread out to occupy a larger proportion of the soil, extending to greater soil depths (Fig. 3a). At the end of the trial (10 weeks after planting), almost $80 \%$ of the soil cells in the first $30 \mathrm{~cm}$ were occupied by roots. This depth is the common depth of soil tillage under shelters. We assume that this high percentage, given the small size of the cells used $(2 \times 2 \mathrm{~cm})$, would be 
Fig. 2 Root-knot nematode infestation in soil and gall index in RKN susceptible crops in the onfarm trial. The two treatments differed only by the cover crop species (sorghum or pepper, in green on the timeline). RKN infestation (a) was measured on soil samples at the end of each crop indicated on the timeline; the mean of seven replicates per treatment \pm standard error are shown. Gall index (b) was measured on the rooting system at the end of each susceptible crop on a scale of $0-10$; the mean of 27 replicates per treatment \pm standard error are shown

\section{Nematodes $/ \mathrm{dm}^{3}$ of soil}

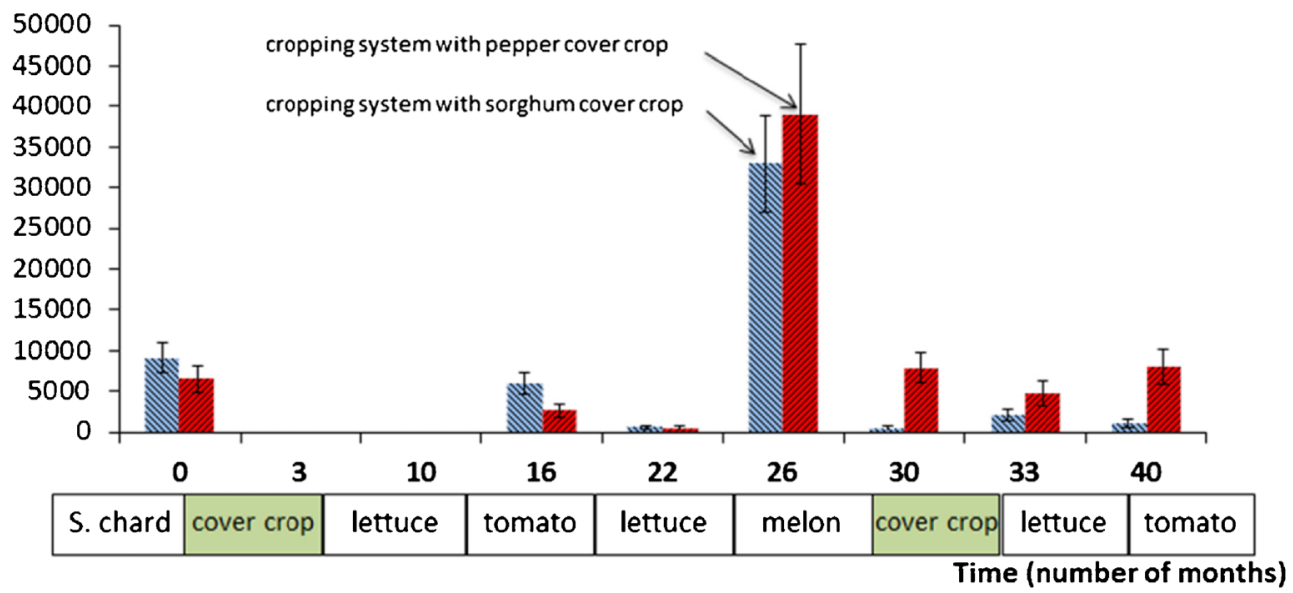

\section{Gall index}

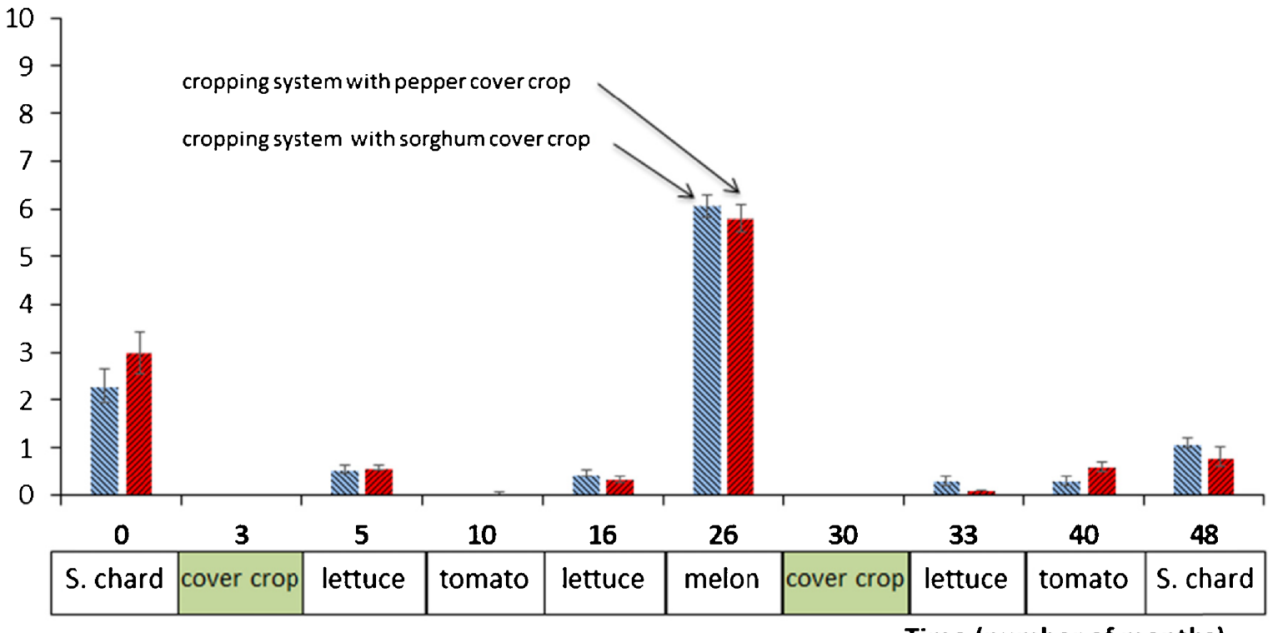

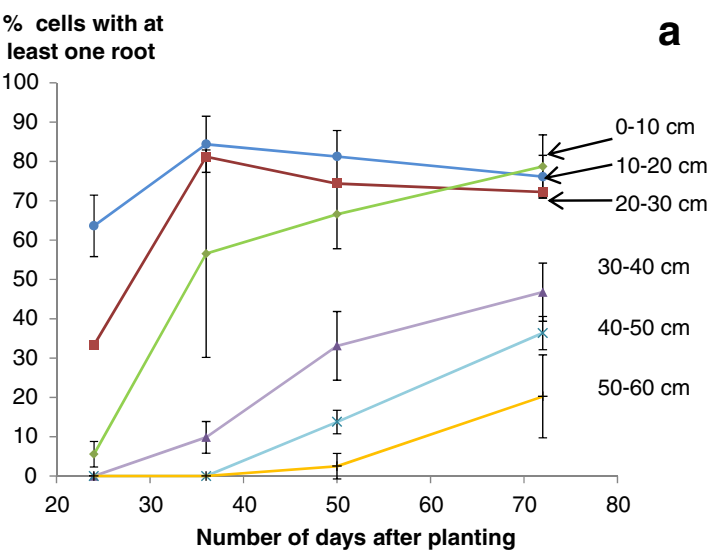

Fig. 3 Soil exploration by the pepper roots in Alénya station. The data indicate the percentage of $2 \times 2$-cm cells of each layer containing at least one root. The means \pm standard error of 15 data per treatment are shown. a The soil exploration by pepper roots is presented for each soil layer of $10-\mathrm{cm}$ depth from the surface, in 2013, for plants cropped at a density of

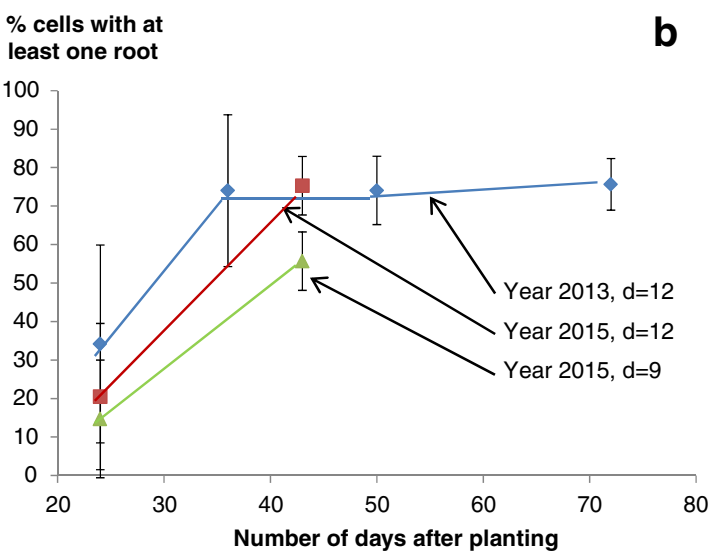

12 plants $/ \mathrm{m}^{2}$. At the end of the cropping cycle, 72 days after planting, more than $70 \%$ of the cells are occupied by at least one root in the first $30 \mathrm{~cm}$. b Two planting densities are tested over 2 years: 9 plants $/ \mathrm{m}^{2}$ in 2015 and 12 plants $/ \mathrm{m}^{2}$ in 2013 and 2015 
sufficient for successful RKN trapping despite the low mobility of RKN juveniles.

Based on these promising results, we investigated, in 2015, the interest of a lower planting density, to decrease nursery and planting costs. With the initial planting density $\left(12\right.$ plants $\left./ \mathrm{m}^{2}\right)$, the percentage of cells occupied by at least one root after 6 weeks was similar to that reported in 2013 (around $75 \%$ of cells occupied) (Fig. 3b). On the contrary, with a planting density of 9 plants $/ \mathrm{m}^{2}$, only $56 \%$ of the cells were occupied by roots in the first $30 \mathrm{~cm}$, a proportion probably too low for satisfactory levels of RKN trapping. The smaller percentage of cells occupied by roots after 3 weeks than in 2013 (21 and $15 \%$ for 12 and 9 plants $/ \mathrm{m}^{2}$, respectively) can be explained by slow growth at the start of the cycle: the seedlings stayed in the nursery for a too long period and their growth was impaired by the high temperatures in the nursery, which delayed root growth. However, one key positive finding was that the Mel-Me3 pepper rooting system has a large potential for soil colonization, for different densities and planting dates (May to July), provided that cropping duration was adapted. This is a major strength for a trap cover crop, because it could be used in various conditions, increasing the likelihood of compliance with the crop schedule constraints of farmers.

\subsubsection{Potential of the resistant pepper as a green manure}

At the end of the pepper crops in Alénya trial, for a density of 12 plants $/ \mathrm{m}^{2}$, the fresh weights of the aerial parts of pepper were $28.7 \mathrm{t} / \mathrm{ha}$ in 2013 and only $7.2 \mathrm{t} / \mathrm{ha}$ in 2015 . The corresponding dry weights were 4.25 and $0.9 \mathrm{t} / \mathrm{ha}$, respectively. In 2013, the amount of fresh organic matter incorporated into the soil was similar to that for sorghum green manure (30.2 t/ha). However, in 2015, water deficiency at first stages was responsible for the very small amount of organic matter produced. The potential interest as a green manure is therefore lower than that of sorghum but satisfactory at a density of 12 plants $/ \mathrm{m}^{2}$. The low density trial should be repeated in better climate conditions, with the seedlings planted in May rather than July, to favor growth and lengthen the cropping cycle, both of which should increase organic matter production.

Moreover, the sorghum and pepper crops had different $\mathrm{C} / \mathrm{N}$ ratios: 28.2 for sorghum and 9.4 and 10.1 for pepper planted at 12 and 9 plants $/ \mathrm{m}^{2}$, respectively. Even if we did not choose pepper for its capacity to enrich the soil in organic matter, these results indicate that it could be considered both as a trap crop and as a green manure, provided that it is grown for at least 2 months and well irrigated. Abawi and Widmer (2000) highlighted the interest of organic matter produced by cover crops to increase microbial activity, improve soil health, and limit RKN infestation, even if the precise mechanisms are not clearly known. Due to a low $\mathrm{C} / \mathrm{N}$ ratio, pepper may rapidly release large amounts of nitrogen into the soil, but it cannot be considered as a green manure capable of increasing the stable humus content of the soil. Rodríguez-Kábana et al. (1987) have considered that the optimal organic amendments were those with a $\mathrm{C} / \mathrm{N}$ ratios between 12 and 20 , because they would both enable nematicidal activity and avoid phytotoxicity. The pepper cover crop is therefore near this optimal range.

In conclusion to the experimental assessment, $\mathrm{Mel}-\mathrm{Me} 3$ pepper can be considered not only as a trap crop but also as an appropriate green manure, even if it seems less effective than sorghum as regards the amount of organic matter produced, rooting potential, and weed suppression capacities.

\subsection{Acceptability of the innovative system to farmers}

In the survey, various views were expressed regarding the cropping system based on pepper trap cover crop. Working time was the key determinant of the three acceptability components considered (compatibility of cropping calendars, work issues, and marketing issues). It was considered a major problem for 12 of the 28 farmers and as a moderate problem for 10 others. Farmers were unhappy with the longer time required for pepper seedling planting than for the sowing of sorghum. Costs were also seen as problematic, due to the high labor costs at planting but particularly for the production of

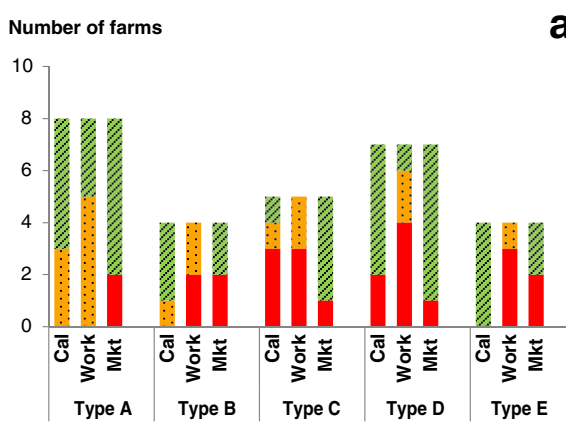

a

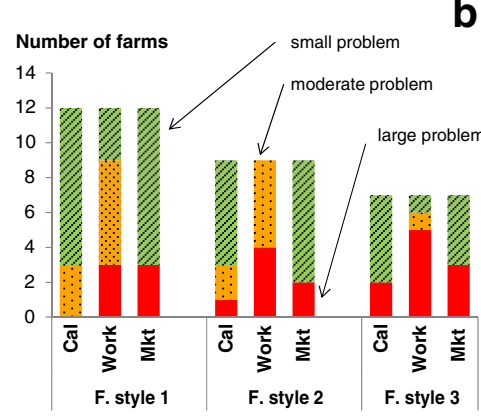

Fig. 4 Effect of farm types (a) and farming styles (b) on the acceptability of the pepper trap crop. The five types of farms and three farming styles were defined on the basis of MCA analyses taking into account the first

five and three axes, respectively, accounting for 74.5 and $80.7 \%$ of the total variability. $(\mathrm{Cal}=$ compatibility of cropping calendars, Work $=$ work issues, $M k t=$ marketing issues) 
pepper seedlings in a nursery. For 19 of the 28 growers, the innovative system was not considered problematic in terms of marketing strategy, because the trap crop was not intended for sale, and because the other species of the innovative cropping system were similar to those usually cropped in the area. Cropping calendars were considered to be fully compatible for 17 farmers and partially compatible for five. As the trap crop occupies the plots for 2 months in the summer, conflicts arose only for the few farms harvesting summer crops (e.g., tomato, sweet pepper cash crops) until September.

The acceptability of the system to farmers clearly depended on the characteristics of the farm and the farmers' strategy (Fig. 4a). Acceptability was highest for the farms of type A (i.e., farms with more than 1 ha of plastic shelters, diversified organic vegetable production, and selling through long marketing channels). The farmers from the other four types found the new cropping system problematic for various reasons. For types B and E, cropping calendars were compatible, but the farms could not afford the increase in workload necessary for pepper planting. For example, type B farms had less than 1 ha of shelters and a workforce consisting entirely of family members. Type E consisted of conventional farms specializing in a small number of crops, with long marketing channels and farming over larger areas (around $10 \mathrm{ha}$ ). These farms employed permanent and seasonal staff, but they were already overstretched by spring crop planting and could not afford to implement the cropping system proposed. Acceptability was lowest in type $\mathrm{D}$, consisting of farms producing diverse vegetables in summer and selling them through short marketing channels: most farmers considered the workload and the cropping calendar unsatisfactory as it would make it difficult to ensure supply for customers in the summer.

The acceptability of the new cropping system also depended on the farming styles (Fig. 4b). The farmers' attitude with respect to agroecology and innovation could even compensate for farm constraints previously shown. Most farmers following farming style 1 were interested in using the new cropping system. This group consisted of very innovative farmers highly motivated to use agroecological practices. Ten of the 12 farmers in this group were organic farmers, who preferred to manage RKN dynamics in the long term, rather than trying to eradicate them immediately. They had already tested alternative green manures, such as Tagetes patula, or natural products to manage RKNs but considered they lack efficiency. By contrast, farmers of farming style 3 were not used to adopting innovative practices on their farms nor motivated to employ agroecological practices. Their RKN management only relied on conventional practices and chemical products. Most of them were reluctant to use the cropping system proposed. The farming style 2 corresponded to an intermediate group, whose points of view were difficult to analyze.

These results on the acceptability of the pepper trap crop echo those from Sattler and Nagel (2010) on the adoption of conservation measures for water, soil, or biodiversity by farmers. They noted that farmers' acceptability tightly depended on their perception of the innovation, the lack of faith in the efficacy of the new practice, the lack of knowhow for its implementation, labor requirements, and risk aversion. They also noted that for some farmers, cost could even be a minor factor compared to the previous ones. We obtained similar responses; some farmers surveyed for the pepper trap crop said that the cost issue could be overcome if the cropping system significantly decreased RKN damage, because they were facing high levels of RKN damages. More generally, these results confirm the interest of a participatory approach to take into account farmers' constraints in designing an innovation and to assess it not only as regards its efficacy but also its feasibility for end-users. Schut et al. (2014) noted that the potential of participatory and systems approach remains largely unexplored for crop protection innovation, and our study is therefore a contribution to help close this gap. By taking into account the organizational, social, and economic factors driving the adoption of innovations, the study enabled to move from a genetic construct (the resistant $\mathrm{Mel}-\mathrm{Me} 3$ pepper) to an agronomic innovation (its use as a trap cover crop to clean soil in a sustainable cropping system). This research process could therefore be very useful for other IPM strategies.

\section{Conclusions}

The study aimed to design and assess a cropping system using an RKN-resistant pepper as a trap cover crop. So far, the use of a resistant plant as a cover crop in vegetable production had been studied in very controlled conditions but never in commercial farm conditions. A participatory research was required to design a crop management plan able to optimize the trapping and to assess it. An in-depth assessment (soil colonization by roots, measurement of gall index on plants and of nematode population in soil, assessment of the farmers' acceptability) had never been realized before this study. Trapping RKNs with the pepper crop was quite effective: soil contamination was much lower after the trap crop and subsequent susceptible crops displayed low levels of RKN damage during 16 months. Moreover, the pepper crop partly served the function of a green manure due to the satisfying amount of fresh organic matter produced. The farm survey showed that this innovative cropping system is appropriate for farms with sufficient labor and land 
available in summer for the duration of the trap crop, especially for intensive large farms. Farms with stronger labor or land constraints would not be able to adopt such a cropping system. Most farmers considered the trap crop to be too expensive, despite their heavy expenditure on chemical nematicide applications every year. The efficiency of trap crop management could still be improved, and various options are being considered to adapt this cropping system to ensure both agronomic efficacy and acceptability to farmers. First, the generation of homozygous genotypes combining the two genes would lower the cost of the seed. A research program to help breeders in the construction of novel resistant pyramid genotypes is currently underway. Second, nursery costs must also be decreased. So far, nurseries are used to generate seedlings for cash crops, with high inputs and high-quality requirements. Nursing practices need to be adapted for the production of cover crop seedlings at a lower price. Third, the optimal density and frequency for the pepper crop, in terms of RKN trapping efficiency, was not determined precisely, and further studies are required to resolve this issue, which directly impacts final cost. Finally, alternatives are required for farmers unable or reluctant to implement this innovation: at plot level, alternating sorghum and pepper cover crops to combine their agronomical and sanitary effects; at farm level, combining different cropping systems to increase the return time for susceptible species. This interdisciplinary research program generated original results in the fields of genetics (e.g., durability of resistance), nematology (e.g., balance between plant-phytoparasitic and free-living species), agronomy (e.g., design and validation of the crop management plan), and agricultural science (e.g., factors affecting the potential for adoption of the practice by farmers). The main issue now is moving from a participatory research study to the development of the cropping system and its adaptation on farms.

Acknowledgments The Gedunem project (2012-2015) was carried out with the financial supports from the French INRA métaprogramme SMaCH-Sustainable Management of Crop Health and from GIS PicLeg. The authors thank Alex Edelman and Associates for their contribution to the English edition.

\section{References}

Abawi GS, Widmer TL (2000) Impact of soil management practices on soil-borne pathogens, nematodes and root diseases of vegetable crops. Appl Soil Ecol 15:37-47. doi:10.1016/S0929-1393(00 )00070-6

Bleve-Zacheo T, Bongiovanni M, Melillo MT, Castagnone-Sereno P (1998) The pepper resistance genes Me1 et Me3 induce differential penetration rates and temporal sequences of root cell ultrastructural changes upon nematode infection. Plant Sci 133:79-90. doi:10.1016 /S0168-9452(98)00021-1

Collange B, Navarrete M, Peyre G, Mateille T, Tchamitchian M (2011) Root-knot nematode (Meloidogyne) management in vegetable crop production: the challenge of an agronomic system analysis. Crop Prot 30:1251-1262. doi:10.1016/j.cropro.2011.04.016

Collange B, Navarrete M, Montfort F, Mateille T, Tavoillot J, Martiny B, Tchamitchian M (2014) Alternative cropping systems can have contrasting effects on various soil-borne diseases: relevance of a systemic analysis in vegetable cropping systems. Crop Prot 55:7-15. doi:10.1016/j.cropro.2013.10.002

Crestin JM, Vannier S (2007) Les engrais verts en maraîchage. Ed. Aprel / CA Vaucluse, $16 p$

Cuadra R, Cruz X, Fajardo JL (2000) Cultivos de ciclo corto Como plantas trampas Para el control del nematodo agallador. Nematropica 30:241-246

Dandurand LM, Brown CR, Knudsen GR, Filip CJ, Gajjar (2013) Potential of Solanum sisymbriifolium as a trap crop for the control of the pale cyst nematode Globodera pallida. J Nematol 45:286-286

Djian-Caporalino C (2012) Root-knot nematodes (Meloidogyne spp.), a growing problem in French vegetable crops. EPPO Bulletin 42:127137

Djian-Caporalino C, Pijarowski L, Januel A, Lefebvre V, Daubeze A, Palloix A, Dalmasso A, Abad P (1999) Spectrum of resistance to root-knot nematodes and inheritance of heat-stable resistance in pepper (Capsicum annuum L.). Theor Appl Genet 99:496-502. doi: $10.1007 / \mathrm{s} 001220051262$

Djian-Caporalino C, Bourdy G, Cayrol JC (2005) Nematicidal and nematode-resistant plants. In: Regnault-Roger $\mathrm{C}$, Philogène $\mathrm{B}$, Vincent C (eds) Biopesticides of plant origin. Tec \& Doc, London, Paris, New York, pp. 173-224

Djian-Caporalino C, Molinari S, Palloix A, Ciancio A, Fazari A, Marteu N, Ris N, Castagnone-Sereno P (2011) The reproductive potential of the root-knot nematode Meloidogyne Incognita is affected by selection for virulence against major resistance genes from tomato and pepper. Eur J Plant Pathol 131:431-440. doi:10.1007/s10658-0119820-4

Djian-Caporalino C, Palloix A, Fazari A, Marteu N, Barbary A, Abad P, Sage-Palloix AM, Mateille T, Risso S, Lanza R, Taussig C, Castagnone-Sereno P (2014) Pyramiding, alternating or mixing: comparative performances of deployment strategies of nematode resistance genes to promote plant resistance efficiency and durability. BMC Plant Biol 14:53-66. doi:10.1186/1471-2229-14-53

Furnion C (2014) Assessing the acceptability of alternative cropping systems limiting the pressure of root-knot nematodes: a case study with market gardeners of South-Eastern France. Engineer dissertation, Wageninen University / ISARA Lyon

Hare WW (1957) Inheritance of resistance to root-knot nematodes in pepper. Phytopathology 47:455-459

Hendy H, Dalmasso A, Cardin MC (1985) Differences in resistant Capsicum annuum attacked by different Meloidogyne species. Nematologica 31:72-78

Hooks CRR, Wang KH, Ploeg A, McSorley R (2010) Using marigold (Tagetes spp.) as a cover crop to protect crops from plant-parasitic nematodes. Appl Soil Ecol 46:307-320

McSorley R, Ozores-Hampton M, Stansly PA, Conner JM (1999) Nematode management, soil fertility and yield in organic vegetable production. Nematropica 29:205-213

Melakeberhan H, Kravchenko A, Dahl J, Warncke D (2010) Effects of soil types and Meloidogyne hapla on the multi-purpose uses of arugula (Eruca sativa). Nematology 12:115-120

Milligan S, Bodeau J, Yaghoobi J, Kaloshian I, Zabel P, Williamson VM (1998) The root knot nematode resistance gene mi from tomato is a member of the leucine zipper, nucleotide binding, leucine-rich repeat family of plant genes. Plant Cell 10:1307-1319 
Navarrete M, Le Bail M, Papy F, Bressoud F, Tordjman S (2006) Combining leeway on farm and supply basin scales to promote technical innovations in lettuce production. Agron Sustain Dev 26: 77-87. doi:10.1051/agro:2005062

Navarrete M, Tchamitchian M, Aissa-Madani C, Collange B, Taussig C (2010) Elaborating innovative solutions with experts using a multicriteria evaluation tool the case of soil-borne disease control in market-gardening cropping systems. International symposium "Innovation and Sustainable Development in Agriculture and Food", Montpellier, June 28 / July 1/2010, http://hal.archivesouvertes.fr/hal-00512273/fr/

Navarrete M, Dupré L, Lamine C (2015) Crop management, labour organization, and marketing: three key issues for improving sustainability in organic vegetable farming. Int J Agric Sustain 13:257-274. doi:10.1080/14735903.2014.959341

Pegard A, Brizzard G, Fazari A, Soucaze O, Abad P, Djian-Caporalino C (2005) Histological characterization of resistance to different rootknot nematode species related to phenolics accumulation in Capsicum annuum L. Phytopathology 95:158-165. doi:10.1094 /PHYTO-95-0158

Ploeg AT, Maris PC (1999) Effects of temperature on the duration of the life cycle of a Meloidogyne Incognita population. Nematology 1: 389-393. doi:10.1163/156854199508388

Prot JC, Van Gundy SD (1981) Effect of soil texture and the clay component on migration of Meloidogyne Incognita second stage juveniles. J Nematol 13:213-219

Roberts PA, Matthews WC, Ehlers JD (2005) Root-knot nematode resistant cowpea cover crop in tomato production systems. Agron J 97: $1626-1635$
Rodríguez-Kábana R, Morgan-Jones G, Chet I (1987) Biological-control of nematodes: soil amendments and microbial antagonists. Plant Soil 100:237-247

Sattler C, Nagel UJ (2010) Factors affecting farmers' acceptance of conservation measures. A case study from North-Eastern Germany. Land Use Pol 27:70-77. doi:10.1016/j.landusepol.2008.02.002

Schut M, Rodenburg J, Klerkx L, van Ast A, Bastiaans L (2014) Systems approaches to innovation in crop protection. A systematic literature review. Crop Prot 56:98-108. doi:10.1016/j.cropro.2013.11.017

Seinhorst JW (1962) Modifications of the elutriation method for extracting nematodes from soil. Nematologica 8:117-128

Sikora RA, Fernandez E (2005) Nematode parasites to vegetables. In: Luc M, Sikora RA, Bridge J (eds) Plant parasitic nematodes in subtropical and tropical agriculture. CAB international, Wallington, pp. 319-392

Thies JA (2011) Virulence of Meloidogyne Incognita to expression of N gene in pepper. J Nematol 43:90-94

Wang KH, McSorley R, Gallaher RN (2003) Host status and amendment effects of cowpea on Meloidogyne Incognita in vegetable cropping systems. Nematropica 33:215-224

Zasada IA, Halbrendt JM, Kokalis-Burelle N, LaMondia J, McKenry MV, Noling JW (2010) Managing nematodes without methyl bromide. Annu Rev Phytopathol 48:311-328. doi:10.1146/annurevphyto-073009-11442

Zeck WM (1971) A rating scheme for field evaluation of root-knot nematode infestations. Pflanzenschutz-Nachrichten 24:141-144 